\title{
HUBUNGAN KECANDUAN BERMAIN GAME ONLINE PADA SMARTPHONE (MOBILE ONLINE GAMES) DENGAN POLA MAKAN ANAK SEKOLAH DASAR KELAS 5 DAN 6 DI SD NEGERI 4 PURWODADI
}

\author{
Oleh; \\ Meity Mulya Susanti ${ }^{1)}$, Wahyu Unggul Widodo ${ }^{2)}$, Darmawati Indah Safitri ${ }^{3)}$ \\ 1) Dosen STIKES An Nur Purwodadi, Email : meityms71@gmail.com \\ 2) Dosen STIKES An Nur Purwodadi, Email: wahyuunggulwidodo@gmail.com \\ 3) Mahasiswa STIKES An Nur Purwodadi, Email: annurlppm@gmail.com
}

\begin{abstract}
ABSTRAK
Latar Belakang: Permainan yang saat ini populer dan marak digemari adalah game online. Kemudahan untuk mengakses game online didukung dengan kehadiran smartphone. Maraknya permainan game online menyebabkan pemain menjadi kecanduan terhadap permainan tersebut. Kecanduan bermain game online tidak hanya terjadi pada orang dewasa tetapi juga bisa terjadi pada anak usia sekolah. Adanya dampak negatif yang ditimbulkan dari kebiasaan sejumlah anak usia sekolah yang gemar bermain game online yaitu salah satunya anak menjadi lebih memilih bermain game online dibandingkan makan kemudian menyebabkan pola makan menjadi tidak teratur atau buruk. Tujuan; untuk mengetahui hubungan kecanduan bermain game online pada smartphone dengan pola makan pada anak sekolah dasar kelas 5 dan 6 di SD Negeri 4 Purwodadi.

Metode: Desain penelitian yang digunakan pada penelitian ini adalah case control yang merupakan penelitian epidemiologic analitik non-ekperimental yang mengkaji hubungan antara efek dengan faktor resiko. Jumlah sampel 80 responden, 40 responden kelompok kasus (pola makan buruk) dan 40 responden kelompok kontrol (pola makan baik), teknik sampling yang digunakan yaitu quota sampling dengan uji hipotesis menggunakan Chi-Square.

Hasil: Hasil menunjukkan dari 40 responden dengan pola makan buruk yang mengalami kecanduan bermain game online pada smartphone sebanyak 30 responden (75\%) dan yang tidak mengalami kecanduan bermain game online pada smartphone sebanyak 10 responden (25\%), dengan $p$ value $=0,000$. Hal ini berarti ada hubungan kecanduan bermain game online pada smartphone dengan pola makan anak sekolah dasar kelas 5 dan 6 di SD Negeri 4 Purwodadi.

Simpulan:Dari hasil penelitian diatas dapat disimpulkan bahwa terdapat hubungan kecanduan bermain game online pada smartphone dengan pola makan anak sekolah dasar kelas 5 dan 6 di SD Negeri 4 Purwodadi.
\end{abstract}

Kata Kunci : Kecanduan Bermain Game Online, Smartphone, Pola Makan Anak Usia Sekolah 


\title{
RELATIONSHIP BETWEEN SMARTPHONE (MOBILE ONLINE GAMES) ONLINE GAMES ADDICTION AND EATING PATTERN ON PRIMARY SCHOOL STUDENTS OF $5^{\text {th }}$ AND $6^{\text {th }}$ GRADE IN SD NEGERI 4 PURWODADI
}

\author{
By; \\ Meity Mulya Susanti ${ }^{1)}$, Wahyu Unggul Widodo ${ }^{2)}$, Darmawati Indah Safitri ${ }^{3)}$ \\ 1) Lecturer of STIKES An Nur Purwodadi, Email : meityms71@ gmail.com \\ 2) Lecturer of STIKES An Nur Purwodadi, Email: wahyuunggulwidodo@gmail.com \\ 3) Student of STIKES An Nur Purwodadi, Email: annurlppm@gmail.com
}

\begin{abstract}
Background: The game that is currently popular and rage is online games. Easy of accessing online games is supported by the presence of smartphone. Online gaming can cause players to become addicted to the game. Addiction to playing online games doesn't only happen in adults but also can occur in school-aged children. The negative impact that can arise from the habits of a number of school-age children who often play online games is one of the children to prefer to play game online that eating, Then cause the eating pattern become irregular or bad. Objective: to know relationship between smartphone (mobile online games) online games addiction and eating pattern on primary school students on $5^{\text {th }}$ and $6^{\text {th }}$ grade In SD Negeri 4 Purwodadi

Methods: The research design used in this study was case contol which was an epidemiologic analytic non-experimental study that reviewing the relationship between the effects and the risk factors. The total sample were 80 respondents, 40 respondents were case group (bad eating pattern) and 40 respondents were control group (good eating pattern), Quota sampling was used as sampling technique and chi-square was used as hypothesis test.

Results: From 40 respondents with bad eating pattern there are 30 respondents $(75 \%)$ addict to playing online games on smartphone and 10 respondents (25\%) do not addict to playing online games on smartphone, with $\rho$ value - 0.000. This means there is a relationship between smartphone (mobile online games) online games addiction and eating pattern on primary school students on $5^{\text {th }}$ and $6^{\text {th }}$ grade In SD Negeri 4 Purwodadi.

Conclusion: It canbe concluded that there is a relationship between smartphone (mobile online games) online games addiction and eating pattern on primary school students on $5^{\text {th }}$ and $6^{\text {th }}$ grade In SD Negeri 4 Purwodadi.
\end{abstract}

Keywords : Online Games Addiction on Smartphone, Eating Pattern, School-Age Children. 


\section{PENDAHULUAN}

Bermain game online di masa sekarang bergitu populer di berbagai kalangan, salah satunya populer di antara anak sekolah, Anak usia sekolah memasuki perkembangan baru tentang bermain dan permainan, pada saat anak memasuki masa sekolah permainan anak menggunakan dimensi baru yang merefleksikan tingkat perkembangan anak yang baru. Maraknya permainan game online menyebabkan pemain menjadi kecanduan terhadap permainan tersebut. (Wong, 2009).

Kecanduan game online (onlinegaming addiction) merupakan penggunaan yang berlebihan terhadap game online, role playing games, atau permainan interaktif melalui internet. Tanda-tanda yang ditunjukkan antara lain, bermain hampir setiap hari dan dalam waktu yang lama (lebih dari 4 jam), merasa gelisah atau pemarah jika tidak dapat bermain, dan mengorbankan kegiatan sosial dan yang lainnya (Young, 2009, h.361-363 dalam Rizky, 2013).

\section{Environment Software Association} (ESA) menunjukkan bahwa data demografi pengguna game online di Amerika bahwa $36 \%$ pengguna game online berusia $<18$ tahun, 32\% berusia 18-35 tahun, dan usia
$36+$ dengan persensentase yaitu $32 \%$ (Purnamawati, 2010).

Direktur Pelaksana PT Megaxus Infotech, Eva Muliawati (2016) mengatakan bahwa di Indonesia secara nasional pengguna game online dari tahun 2016 terdapat setidaknya 6,5 juta pengguna game online/video game naik menjadi 500 ribu pengguna game online. jumlah ini diperkirakan akan terus meningkat.

APJII (Asosiasi Penyelenggara Jasa Internet Indonesia, 2016) menyatakan perangkat bermain game online paling banyak menggunakan perangkat mobile (smartphone) sebesar 89,9 juta atau sekitar $67,8 \%$. sedangkan menurut riset dari Newzoo (2016), pengguna game sepanjang tahun 2016 diprediksi akan terus meningkat pesat sampai tahun 2019. Riset Newzoo juga menunjukkan Indonesia merupakan negara dengan jumlah gamer terbanyak yang bermain di perangkat mobile (smarphone).

Data terbaru yang dirilis oleh NPD Group bertajuk mobile gaming (2014) menunjukkan pemain game mobile yaitu mereka yang bermain pada smartphone, Ipod touch atau tablet yang bermain lebih sering dan dalam waktu yang lebih lama dibanding 2 tahun yang lalu. Rata-rata waktu yang dihabiskan dalam bermain game meningkat menjadi 57\% menjadi lebih dari 
2 jam perhari pada tahun 2014 dibandingkan 1 jam dan 20 menit pada tahun 2012 yang lalu. Rata-rata jumlah waktu bermain di tingkat tertinggi ada pada rentang usia 6 44 tahun. Anak-anak usia $2-12$ tahun menghabiskan proporsi waktu mereka untuk bermain game daripada kegiatan lainnya. Mereka menghabiskan waktu rata-rata 2 jam atau lebih untuk bermain game. Hasil survei tersebut tampak jelas bahwa anak-anak saat ini banyak yang sudah kecanduan bermain game online terutama melalui perangkat smartphone maupun tablet berbasis android.

Sanditaria, dkk (2012) mengemukakan dari hasil penelitian dengan menggunakan 71 responden anak usia sekolah yang bermain game online dimana 38\% responden termasuk dalam kategori tidak adiksi (tidak kecanduan) dan 62\% responden termasuk dalam ketegori adiksi (kecanduan). Beberapa kasus tercatat, terdapat beberapa gamers yang addicted dengan game online menghabiskan waktu demi bermain game tersebut dan sampai lupa untuk tidak mandi, makan, apalagi untuk melaksanakan tugas yang merupakan kewajibannya.

Anak dianggap lebih sering dan rentan terhadap penggunaan permainan game online daripada orang dewasa, terutama anak sekolah dasar. Hurlock (2013) mengemukakan bahwa anak sekolah dasar terutama di usia 10-12 tahun lebih memahami dan masih suka bermain, bergerak dan menyukai permainan yang mempunyai nuansa persaingan sehingga membuat pemainnya akan bermain terusmenerus tanpa memperdulikan berapa lama waktu yang dipergunakan.

Kekhawatiran terhadap adanya dampak negatif yang ditimbulkan dari kebiasaan sejumlah anak usia sekolah yang gemar bermain game online yang mampu mengambil alih kehidupan anak. Salah satu dampak dari permainan ini adalah dari segi jasmani (kesehatan menurun) karena anakanak yang terlalu sering bermain game memiliki daya tahan tubuh yang lemah akibat kurangnya aktivitas fisik, duduk terlalu lama, sering terlambat makan (Telkomsel, 2017).

Anak yang lebih memilih bermain game online dibandingkan makan biasanya memiliki pola makan yang cenderung tidak teratur atau buruk. Padahal diketahui bahwa dengan pola makan yang sehat dan teratur, kondisi fisik tubuh akan lebih terjamin sehingga tubuh akan dapat melakukan aktifitasnya dengan baik pula. Begitu pula halnya dengan anak-anak, Anak yang sehat akan tampak lebih lincah, kreatif dan bersemangat belajar. Hal ini karena kebutuhan tubuh dapat dipenuhi dengan baik 
sehingga organ-organ tubuh akan melakukan fungsinya dengan baik pula. Sebaliknya, bila tubuh kekurangan suatu zat gizi tertentu, maka daya tahannya juga akan menurun.Kemampuan kerjanya melemah. Dan bila berkelanjutan akan dapat menimbulkan suatu penyakit saluran pencernaan salah satunya seperti gastritis (Hardani, 2012).

Anak yang memiliki pola makan tidak teratur, mudah terserang penyakit seperti gastritis karena pada saat perut harus diisi, tapi dibiarkan kosong atau ditundanya pengisian, asam lambung kosong dan akan terjadi gerakan peristaltik lambung bertambah intensif yang akan merangsang peningkatan produksi asam lambung sehingga dapat timbul rasa nyeri diulu hati (Ikawati, 2010).

Anak usia sekolah membangun pola makan yang terlepas dari pengawasan orang tua, lalu pada proses pertumbuhan ini anak diperkenalkan pada pola makan yang baik dan teratur, tetapi lupa diri ketika sedang bermain, sehingga anak-anak tidak ingin mengkonsumsi makanan dan pola makan menjadi tidak teratur. Anak yang gemar bermain game online dengan frekuensi dan durasi bermain yang cukup lama beresiko memiliki status gizi kurus karena terlalu fokus bermain game online.
Riset Kesehatan Dasar (RISKESDAS) (2014) mengungkapkan Di Yogyakarta untuk kategori status gizi umur 6-12 tahun ditemukan prevalensi status gizi kategori Indeks Masa Tubuh (IMT/U) ditemukan 2,7\% sangat kurus, 5,9\% kurus dan 7,8\% gemuk (Purnamawati, 2010).

Berdasarkan studi pendahuluan yang dilakukan oleh peneliti di 5 SD meliputi : SDN 1, 2 dan 7 Kuripan, SDN 10 Purwodadi dan SDN 12 Purwodadi, siswanya membawa gadget $\leq 50 \%$, Hal ini dikarenakan faktor ekonomi orang tua yang kurang dan peraturan sekolah yang memang melarang siswanya membawa gadget. Berbeda dengan SD yang berada di perkotaan Kecamatan Purwodadi yang cenderung anak-anak usia SD yang mempunyai gadget dikarenakan perekonomian orang tua siswa sekolah di perkotaan berkecukupan dan orang tua memberi kebebasan anak untuk membawa gadget.

Hasil dari observasi dan wawancara yang peneliti lakukan pada siswa kelas 5 dan 6 di SD Negeri 4 Purwodadi. Peneliti menemukan terdapat 25 siswa kelas 5 dari 50 siswa dan 35 siswa kelas 6 dari 50 siswa yang membawa gadget dan bermain game online pada smartphone (mobile online games). Biasanya siswa tersebut melakukan 
aktivitas bermain game online pada smartphone (mobile online games) pada saat sebelum tanda bel waktu masuk berbunyi, saat jam kosong dan tidak ada guru dan pada saat waktu istirahat sekolah.

Hasil wawancara singkat dengan 10 siswa kelas 5 dan 6 mengenai intensitas dalam bermain game online pada smartphone dan pola makan siswa apabila sedang ada dirumah, Terdapat 3 siswa mengatakan pulang dari sekolah tidak istirahat tidur melainkan mereka melanjutkan bermain game online pada smartphone (mobile online games) dengan frekuensi 4-7 kali dalam sehari dan durasi bermain game online selama 1-2 jam dan 7 siswa lainnya mengatakan bermain game online dengan frekuensi 5-10 kali dalam sehari dan durasi selama lebih dari 3-5 jam, Bahkan sampai lupa waktu dalam menyelesaikan tugas sekolah dan melakukan tugas yang lainnya, mereka juga mengatakan tidak nafsu makan dan tidak ingin makan ketika sedang asyik bermain game online pada smartphone (mobile online games) sampai melupakan waktu makan yang seharusnya jadwal makannya tepat waktu menjadi telat hingga lupa tidak makan sehingga pola makan menjadi tidak teratur.

Berdasarkan latar belakang yang peneliti paparkan diatas, peneliti tertarik untuk meneliti bagaimana hubungan antara kecanduan bermain game online (mobile online games) dan pola makan pada anak usia sekolah dasar dengan judul "Hubungan kecanduan bermain game online pada smartphone (mobile online games) dengan pola makan pada anak kelas 5 dan 6 di SD Negeri 4 Purwodadi”.

\section{METODE}

Desain penelitian yang digunakan adalah penelitian kuantitatif dengan jenis studi perbandingan (comparative study) dengan rancangan Case Control yang merupakan penelitian epidemiologic analitik non-ekperimental yang mengkaji hubungan antara efek dengan faktor resiko (Notoatmodjo, 2010).

Pada penelitian ini responden akan dibagi menjadi 2 kelompok yaitu kelompok kasus dan kelompok kontrol. kelompok kasus yaitu responden dengan pola makan buruk dan kelompok kontrol responden dengan pola makan baik. kelompok kasus dan kelompok kontrol diberikan kuesioner yang sama tentang pola makan dan kecanduan bermain game online pada smartphone. Teknik sampling yang digunakan dalam penelitian ini adalah tehnik Non Probability Sampling dengan menggunakan tehnik quota sampling yaitu 
tehnik pengambilan sampel dengan cara menetapkan jumlah tertentu sebagai target yang harus dipenuhi dalam pengambilan sampel dari populasi (Notoatmodjo, 2010).

Dalam penelitian ini didapatkan sampel sebanyak 80 responden, variabel independen dalam penelitian ini adalah kecanduan bermain game online pada smartphone (mobile online games) dan variabel dependen dalam penelitian ini adalah pola makan. Metode pengumpulan data yang digunakan dalam penelitian ini adalah kuesioner. Alat pengukuran yang digunakan dalam penelitian ini adalah kuesioner pola makan dan kecanduan bermain game online pada smartphone (mobile online games). Uji statistik yang digunakan dalam penelitian ini dengan menggunakan uji Chi-Square.

HASIL

Tabel 1 Distribusi Frekuensi Responden Kelompok Pola Makan Buruk

\begin{tabular}{cccc}
\hline & Umur (Tahun) & f & $\mathbf{( \% )}$ \\
\hline 11 & & 18 & 45 \\
12 & & 22 & 55 \\
\hline & Total & $\mathbf{4 0}$ & $\mathbf{1 0 0}$ \\
\hline
\end{tabular}

Tabel 2 Distribusi Frekuensi Responden

Kelompok Pola Makan Baik

\begin{tabular}{cccc}
\hline & Umur & $\mathbf{f}$ & $\mathbf{( \% )}$ \\
\hline 11 & & 28 & 70 \\
12 & & 12 & 30 \\
\hline & Total & $\mathbf{4 0}$ & $\mathbf{1 0 0}$ \\
\hline
\end{tabular}

Tabel 3 Distribusi Frekuensi Responden Kelompok Pola Makan Buruk

\begin{tabular}{lcc}
\hline \multicolumn{1}{c}{ Jenis Kelamin } & f & (\%) \\
\hline Laki-Laki & 22 & 55 \\
Perempuan & 18 & 45 \\
\hline Total & $\mathbf{4 0}$ & $\mathbf{1 0 0}$ \\
\hline
\end{tabular}

Tabel 4 Distribusi Frekuensi Responden Kelompok Pola Makan Baik

\begin{tabular}{|c|c|c|}
\hline Jenis Kelamin & $\mathbf{f}$ & $(\%)$ \\
\hline Laki-Laki & 16 & 40 \\
\hline Perempuan & 24 & 60 \\
\hline Total & 40 & 100 \\
\hline
\end{tabular}


Tabel 5 Distribusi Kecanduan Bermain Game Online Pada Smartphone

Dengan Pola Makan

\begin{tabular}{|c|c|c|c|c|c|}
\hline & & & Pola_Maka & 1.Anak_SD & \\
\hline & & & $\begin{array}{c}\text { Pola Makan } \\
\text { Baik }\end{array}$ & $\begin{array}{c}\text { Pola Makan } \\
\text { Buruk }\end{array}$ & Total \\
\hline Kecanduan. & Kecanduan Bermain & Count & 10 & 30 & $\overline{40}$ \\
\hline Bermain_ & Game Online & Expected Count & 20.0 & 20.0 & 40.0 \\
\hline Game. & Tidak Kecanduan & Count & 30 & 10 & 40 \\
\hline OmmIne & Bermain Game Online & Expected Count & 20.0 & 20.0 & 40.0 \\
\hline & & Count & 40 & 40 & 80 \\
\hline & & Expected Count & 40.0 & 40.0 & 80.0 \\
\hline
\end{tabular}

Tabel 6 Pearson Chi-Square

\begin{tabular}{|c|c|c|c|c|c|}
\hline & Value & Df & $\begin{array}{l}\text { Asymp. Sig. } \\
\text { (2-sided) }\end{array}$ & $\begin{array}{c}\text { Exact Sig. (2- } \\
\text { sided) }\end{array}$ & $\begin{array}{c}\text { Exact Sig. (1- } \\
\text { sided) }\end{array}$ \\
\hline Pearson Chi-Square & $20.000 \mathrm{a}$ & 1 & .000 & & \\
\hline$\overline{\text { Continuity Correction }^{\mathrm{b}}}$ & 18.050 & 1 & .000 & & \\
\hline Likelihood Ratio & 20.930 & 1 & .000 & & \\
\hline Fisher's Exact Test & & & & .000 & .000 \\
\hline Linear-by-Linear Association & 19.750 & 1 & .000 & & \\
\hline $\mathrm{N}$ of Valid Cases ${ }^{\mathrm{b}}$ & 80 & & & & \\
\hline
\end{tabular}

\section{PEMBAHASAN}

Berdasarkan hasil penelitian uji univariat diketahui bahwa dari kelompok pola makan buruk mayoritas mengalami kecanduan bermain game online pada smartphone sedangkan sampel penelitian kelompok kontrol/kelompok pola makan baik mayoritas tidak kecanduan bermain game online pada smartphone. Sedangkan, uji bivariat dengan menggunakan uji chisquare didapatkan hasil uji antara pola makan dengan kejadian kecanduan game 
online pada smartphone diketahui $\mathrm{p}(0,000)$ $<\alpha(0,05)$.

Dari hasil tersebut dapat disimpulkan Ha diterima $\mathrm{H}_{0}$ ditolak yang artinya terdapat hubungan kecanduan bermain game online pada smartphone dengan pola makan anak sekolah dasar kelas 5 dan 6 di SD Negeri 4 Purwodadi. Berdasarkan hasil diatas peneliti beranggapan bahwa kecanduan bermain game online pada smartphone menyebabkan pola makan yang buruk.

Menurut Penelitian yang dilakukan oleh Gentile (2012) menyatakan bahwa lebih dari 8,0\% gamers berusia 8-18 tahun. Dari responden survey, paling banyak anak yang berusia 11-13 tahun keatas memperlihatkan tanda kecanduan video game dan rata-rata mereka menghabiskan waktu bermain game untuk anak laki-laki 16,4 jam dan perempuan 9 jam di setiap minggunya.

Menurut penelitian yang dilakukan Ardanareswari Ayu Pitaloka (2013) tentang perilaku konsumsi game online pada pelajar yang menyebutkan bahwa sejauh ini game online paling banyak dimainkan oleh pelajar laki-laki dibanding perempuan dalam rentang usia wajib belajar yaitu (7-18 tahun) dan sisanya adalah masyarakat umum dari semua kalangan usia maupun profesi.
Hasil penelitian ini diperkuat juga oleh penelitian sebelumnya oleh Niko Mannikko Joel Billieux \& Maria Kaariainen Penelitian dengan judul "Hubungan Perilaku Kecanduan Game Digital Dengan Psikologis, Kesehatan Fisik Dan Sosial Pada Remaja Finlandia Dan Dewasa Muda" Dengan sampel 293 responden berusia 13 sampai 24 tahun. Perilaku kecanduan game diukur dengan Game Adicction Skala (GAS). Hasilnya : Perilaku kecanduan game itu ditemukan berhubungan dengan masalah psikologis dan kesehatan, yaitu kelelahan, gangguan tidur, pola makan tidak teratur, gangguan pencernaan, depresi dan kecemasan. Kesimpulan dari hasil tersebut yaitu Penelitian ini ditekankan perilaku kecanduan game tersebut memiliki korelasi negatif yang kuat dengan beragam hasil masalah psikologis dan kesehatan.

Dari penelitian yang dilakukan sebelumnya bahwa gangguan pola makan menjadi suatu dampak bagi para pecandu game online. Hal ini dibuktikan dari penelitian Jemilatun Asih tentang "Pengaruh Game Online Terhadap Pola Makan Anak Usia Sekolah Di Rw 02 Kelurahan Jomblang Kota Semarang" Hasilnya anak yang bermain game online mayoritas pada kategori cukup yang berjumlah 20 responden (66.7\%). Mayoritas responden 
memiliki pola makan pada kategori cukup yang berjumlah 17 responden (56.7\%). Didapatkan hasil $\mathrm{p}=0.007$ dari hasil tersebut menunjukan bahwa $\mathrm{p}$ value $<0.05$ jadi terdapat pengaruh kecanduan game online terhadap pola makan anak usia sekolah di RW 02 Keluraan Jomblang Kota Semarang.

Berdasarkanpenelitian yang dilakukan oleh (Zulfanida Karuniasari, 2017) dengan judul peran kontrol sosial dalam menghadapi kecanduan game online pada remaja jurusan psikologi dan pendidikan agama islam fakultas psikologi dan agama islam. Hasil penelitian menunjukkan bahwa kecanduan game online yang dialami remaja berawal tersedianya perangkat game sejak usia belia ( \pm 5 - 10 tahun). Alasan informan suka game online 1) menarik dan membuat ketagihan, 2) menambah teman dan keuntungan, 3) tampilan gambar yang menarik. Intensitas waktu bermain game rata-rata \pm 25 jam/minggu.

Hal ini diperkuat pula dengan penelitian yang telah dilakukan oleh (Khoirotun Nisak, dkk, 2016) dengan judul hubungan problematika permainan video game dengan perilaku, personal hygiene, dan status gizi pada remaja fakultas kedokteran dan ilmu kesehatan. Hasilnya menunjukkan bahwa video game berdampak pada kesehatan remaja. Berdiam di depan perangkat permainan video game terlalu lama sering mengakibatkan remaja lupa untuk makan, belajar, tidur dan beraktivitaslainnya. Konsekuensinya, remaja akan mengalami kekurangan nutrisi karena tidak memperhatikan asupan nutrisi yang tepat dan teratur atau mungkin malah obesitas karena kurangnya aktivitas fisik.

Chaplin (2004) mengemukakan dalam aspek ini melihat seberapa lamakah seseorang bermain game online dalam sehari. Semakin lama seseorang bermain game online dapat membuktikan sebagian waktu yang mereka miliki hanya mereka gunakan untuk bermain game online bahkan hanya karena game online seseorang bisa melupakan waktu untuk makan, mandi sehingga aktivitas sehari-hari mereka menjadi tidak seimbang lagi. Seseorang yang bermain game online terkadang juga untuk meningkatkan hubungan dengan teman-teman sebayanya karena lingkungan teman yang sering bermain game online dapat membuat seseorang untuk ikut bermain karena tidak ingin dipandang berbeda oleh teman-temannya. Emosi seseorang juga terlibat. Seseorang akan merasa senang saat dapat menang disetiap tantangan yang ada atau seseorang dapat merasa sangat kecewa saat mengalami kekalahan. Emosi juga akan tampak saat 
seseorang berbagi pengalaman tentang permainannya dengan teman-temanya

\section{SIMPULAN}

1. Setelah memberikan kuesioner tentang pola makan pada responden yang memiliki pola makan buruk responden yang kecanduan bermain game online pada smartphone sebanyak 30 orang dan yang tidak kejadian kecanduan game online pada smartphone sebanyak 10 orang, sedangkan yang memiliki pola makan baik dengan kejadian kecanduan game online pada smartphone sebanyak 10 orang dan tidak kejadian kecanduan game online pada smartphone sebanyak 30 orang.

2. Setelah dilakukan uji hipotesis untuk mengetahui apakah ada hubungan kecanduan bermain game online pada smartphone dengan pola makan anak kelas 5 dan 6 di SD Negeri 4 Purwodadi. Dari hasil uji chi-square didapatkan nilai $\mathrm{p}(0,000)<\alpha(0,05)$. Jadi, dari hasil tersebut dapat disimpulkan Ha diterima $\mathrm{H}_{0}$ ditolak yang artinya terdapat hubungan kecanduan bermain game online pada smartphone dengan pola makan anak sekolah dasar kelas 5 dan 6 di SD Negeri 4 Purwodadi
DAFTAR PUSTAKA

APJII, Asosiasi Penyelenggara Jasa Internet Indonesia (2016) . Data Statistik Pengguna Internet Indonesia Tahun 2016. From http://isparmo.web.id 2016/11/21/ datastatistik-pengguna- internetindonesia- 2016/ diakses : Rabu, 17 Januari 2018.

Asih, Jamilatun. (2015). PengaruhBermain Game Online Terhadap Pola Makan Anak Usia Sekolah Di Kelurahan Jomblang Kota Semarang. Undergruated Thesis, Fakultas Ilmu Keperawatan Universitas Sultan Agung: Semarang. repository.unissula.ac.id.

Chaplin, J. P. (2004). Kamus Lengkap Psikologi. Jakarta : PT Raja

Grafindo Perkasa. Gentile, D. (2012). Pathological videogame use among youth ags 8-18. Journal of the Association for Psychological Science, 1-9.

Hardani. Rika. (2010). Pola Makan Sehat. Kharisma Woman And Education.

Hurlock, E. B. (2013). Perkembangan Anak Jilid 1 Edisi Ke-6. Jakarata : Erlangga.

Ikawati, Z. (2010). Resep Hidup Sehat. From : http://books.google.co.id/.

Karuniasari, Zulfanida. (2017). Peran Kontrol Sosial Dalam Mengahdapi Kecanduan Game Online Pada Remaja. UMS : Surakarta.

Muliawati, E. (2016). Jumlah Gamer Online Indonesia Terus Tumbuh. Jakarta : Republika.From: http://www.republika. co.id/berita/trendtek/internet/11/09/16/lr 
lxg4-jumlah-gamer-online-indonesiaterus-tumbuh

Niko. Manniko. dkk. (2015). Problematic Digital Gaming Behavior And Its Relation To The Psychological, Social And Physical Health Of Finnish Adolescents And Young Adults. Journal of Behavioral Addictions 4(4), pp. 281288. DOI: 10.1556/2006.4.2015. 040.

Nisak, Khoirotun. dkk. (2016). Hubungan Problematika Permainan Video Game Dengan Perilaku,Personal Hygiene Dan Status Gizi Pada Remaja. Fakultas Kedokteran Dan Ilmu Kesehatan. UMY : Yogyakarta.

Notoatmodjo, S. (2010). Metodologi Penelitian Kesehatan. Jakarta : Rineka Cipta.

NPD Group (2014). Rata- Rata Dua Jam Dihabiskan Anak-Anak Untuk Main Game. Internet Sehat. From : https://internetsehat.id /2015/01/ratarata-dua-jam-dihabiskan-anak- anakuntuk-main-game/

Pitaloka, Ardanareswari Ayu. (2013). Perilaku Konsumsi Game Online Pada Pelajar: Studi Fenamenalogi Tentang Perilaku Konsumsi Game Online Pelajar Di Kelurahan Gemolong Kabupaten Sragen. Solo : Universitas Sebelas Maret.
Purnamawati, Ita. (2014). Hubungan Permainan Video Game Dengan Pola Makan Status Gizi Anak Usia Sekolah Di SD Muhammadiyah Condong Catur Sleman. UMY. From: repository.umy. ac.id.

RISKESDAS. Badan Penelitian Dan Pengembangan Kesehatan Pementrian Kesehatan RI. (2014).

Rizky, M. R . \& Siswati (2013). Hubungan Antara Kelekatan Terhadap Ayah Dengan Kecenderungan Kecanduan Game Online Pada Remaja Laki-Laki Pengguna Game Online Di Kabupaten Grobogan. Fakultas Psikologi. Universitas Diponegoro : Semarang. From : ejournal3.undip.ac.id.

Sanditaria, dkk. (2012). Adiksi Bermain Game Online Pada Anak Usia Sekolah Di Warung Internet Penyedia Game Online Jatinangor Sumedang. Karya Tulis Ilmiah Ilmu Keperawatan Universitas Padjadjaran. From : jurnal.unpad.ac.id.

Telkomsel, (2017). Rumus Keren Internet Baik Bertanggung Jawab, Aman, Inspiratif Dan Kreatif Hal. 44 (Game Di Internet).Jakarta : Direktur PT. Telkomunikasi Selular

Wong, L. (2009). Buku Ajar Keperawatan Pediatrik Vol. 1 Edisi 6.Jakarta:EGC 